\title{
Influence of weather parameters on tikka (Cercospora spp.) and rust (Puccinia arachidis) of groundnut (Arachis
} hypogaea L.)

\author{
S.G. KANADE, A.A. SHAIKH, J.D. JADHAV AND C.D. CHAVAN
}

Article Chronicle :

Received :

29.01.2015;

05.04.2015;

Accepted :

28.04.2015

Key Words :

Weather

parameter, Tikka,

Rust, Groundnut
ABSTRACT : The experiment was laid out in Randomized Block Design with five sowing dates viz., $\mathrm{S}_{1}$ $-22^{\text {nd }}$ June, $S_{2}-29^{\text {th }}$ June, $S_{3}-6^{\text {th }}$ July, $S_{4}-13^{\text {th }}$ July and $S_{5}-20^{\text {th }}$ July and four replications. The data revealed that in case of tikka disease there was positive significant correlation between disease intensity and maximum temperature (0.66), morning relative humidity (0.34), evaporation $(0.39)$ and bright sunshine hours $(0.65)$, whereas, minimum temperature $(-0.55)$, evening relative humidity $(-0.69)$, wind speed ($0.73)$ and rainy days $(-0.26)$ showed negatively significant correlation with disease intensity in Kharif season and wind speed, rain and rainy days are responsible for development tikka disease intensity. In rust disease maximum temperature (0.59), morning relative humidity (0.33), evaporation ( 0.33$)$ and bright sunshine hours $(0.55)$ showed positive correlation with disease intensity. Whereas, minimum temperature $(-0.44)$, evening relative humidity $(-0.58)$ and wind speed (-0.63), showed negatively significant correlation with disease intensity in Kharif season. Other climatic factors i.e., rainfall showed no significant correlation with disease intensity. The morning relative humidity and bright sunshine hours were correlated for rust disease incidence. From the multiple regression it is seen that the tikka disease severity was significantly related with wind speed (-5.53), rain (0.12) and rainy days (-4.46) and these factors were found to be significantly superior among the all weather parameters. The multiple regression equation developed is: $\mathrm{Y}=66.750-5.536 \mathrm{WS}^{(\mathrm{W}-1)}+0.124 \mathrm{RAIN}^{(\mathrm{W}-1)}-4.463 \mathrm{RAINY}^{\mathrm{DAY}} \mathrm{S}^{(\mathrm{W}-1)}$. The result from all the relevant observations indicated that the morning relative humidity (2.87) and bright sunshine hours (5.65) during the crop growing period was found to be highly significant weather conditions for rust disease development among the all other weather parameters. The multiple regression equation developed is as: $\mathrm{Y}=-257.591+2.879 \mathrm{RH}^{\mathrm{I}} \mathrm{I}^{(\mathrm{W}-1)}+5.651 \mathrm{BSS}^{(\mathrm{W}-1)}$.

How to CITE THIS ARTICLE : Kanade, S.G., Shaikh, A.A., Jadhav, J.D. and Chavan, C.D. (2015). Influence of weather parameters on tikka (Cercospora spp.) and rust (Puccinia arachidis) of groundnut (Arachis hypogaea L.). Asian J. Environ. Sci., 10(1): 39-49.

Author for correspondence :

\section{J.D. JADHAV}

Zonal Agricultural

Research Station, SOLAPUR (M.S.) INDIA

Email: slp.aicrpam

@ gmail.com 